Insect Pests

\title{
A COMPARISON OF CHEMICALS FOR THE CONTROL OF NYSIUS ON BRASSICAS
}

\author{
T. E. T. TROUGHT
}

Soil and Field Research Organisation, MAF, Christchurch

\author{
Summary
}

Trials in which a variety of insecticides were field tested against nysius (Nysius huttoni) are described. Compared with the standard parathion-methyl, practical rates of dicrotophos, trichloronat, chlorpyrifos and a mixture of omethoate and azinphos-ethyl gave equivalent control.

\section{INTRODUCTION}

In January 1972 attacks by nysius (Nysius huttoni) in Canterbury on fodder crop brassicae were causing concern and crop loss. Parathion-methyl had been the most commonly used insecticide against this pest which, by puncturing and feeding at the base of the stems of seedlings may cause their death. Shortly bəfore these attacks began, in December 1971, it became illegal under the Agricultural Chemicals (Parathion and Parathionmethyl) Notice 1971 to apply parathion or parathion-methyl to field crops except under permit.

At that time no reasonable alternatives to parathion-methyl for the control of nysius could be recommended and work to discover suitable alternatives started immediately.

This paper describes the tests carried out in 1972 and 1973 which have led to the use of alternatives to parathion and parathion-methyl for the control of nysius.

\section{METHOD}

It had been observed that the distribution of nysius over some areas of some paddocks was relatively even; it was considered therefore that, with careful selection of sites, a single replicate of each candidate chemical would be adequate for preliminary screening (Table 1). Initially in 1972 the chemicals were applied by knapsack sprayer to plots $1 \mathrm{~m} \times 20 \mathrm{~m}$ in extent. Plot sizes were increased later to $5 \mathrm{~m} \mathrm{x} 20 \mathrm{~m}$ to reduce the risk of the assessments becoming complicated by invasion of the pest from outside. Sprays were applied at 260 litres/ha at a presure of $138 \mathrm{kPa}$.

In 1973 those chemicals which had shown promise were tested in replicated trials with plot sizes increased to $10 \mathrm{~m} \times 25 \mathrm{~m}$ (Table 2). Sprays were applied at 160 litres/ha at a pressure of $280 \mathrm{kPa}$.

In 1972 the density of living nysius on treated plots was scored by eye with a score of 0 for no visible bugs up to 10 for high numbers easily visible. Ten areas each of approximately $0.75 \mathrm{~m}^{2}$ each including not less than ten seedling turnips were scored in this fashion in each plot.

In 1973 more precise measurements of bug numbers were obtained by counting the numbers visible around groups of five plants. Six such groups were counted in each plot. In order to determine the efficiency of this method of visual assessment one trial was sampled immediately after the assessment by a sieving and flotation technique carried out in the field (Table 3). This technique consisted of removing a core of soil $8 \mathrm{~cm}$ in diameter and $1.5 \mathrm{~cm}$ deep around a seedling without allowing the nysius to escape. This sample was immediately sieved through two super-

Proc. 28th N.Z. Weed and Pest Control Conf. 
imposed sieves; the top with mesh width $2.5 \mathrm{~mm}$, the lower with $1.25 \mathrm{~mm}$. Rubbish was retained in the top sieve, dust passed through both and the bugs with some soil were retained in the lower sieve, the content of which was quickly plunged into a $600 \mathrm{ml}$ beaker half full of water. Speed was essential since on warm days nysius are very lively. All the nysius with some debris floated in the beaker and those that were alive were counted as they were removed. Since the estimated number of nysius surviving after chemical treatment had been the basis for the visual scoring technique it was of importance that the living bugs could be distinguished from the dead in this flotation technique. The technique was checked and found to be efficient by the addition and subsequent extraction of known numbers of living nysius in prepared tes samples.

From the author's experience unreliable results are obtained if samples are bagged, removed from the field, stored and later extracted with strong salt solution; too many bugs succumb.

\section{RESULTS}

The tables are shown in Tables 1,2 and 3.

TABLE 1: SUMMARY OF THE EFFECTS OF VARIOUS INSECTICIDES AGAINST NYSIUS ON SEEDLING BRASSICAE-1972

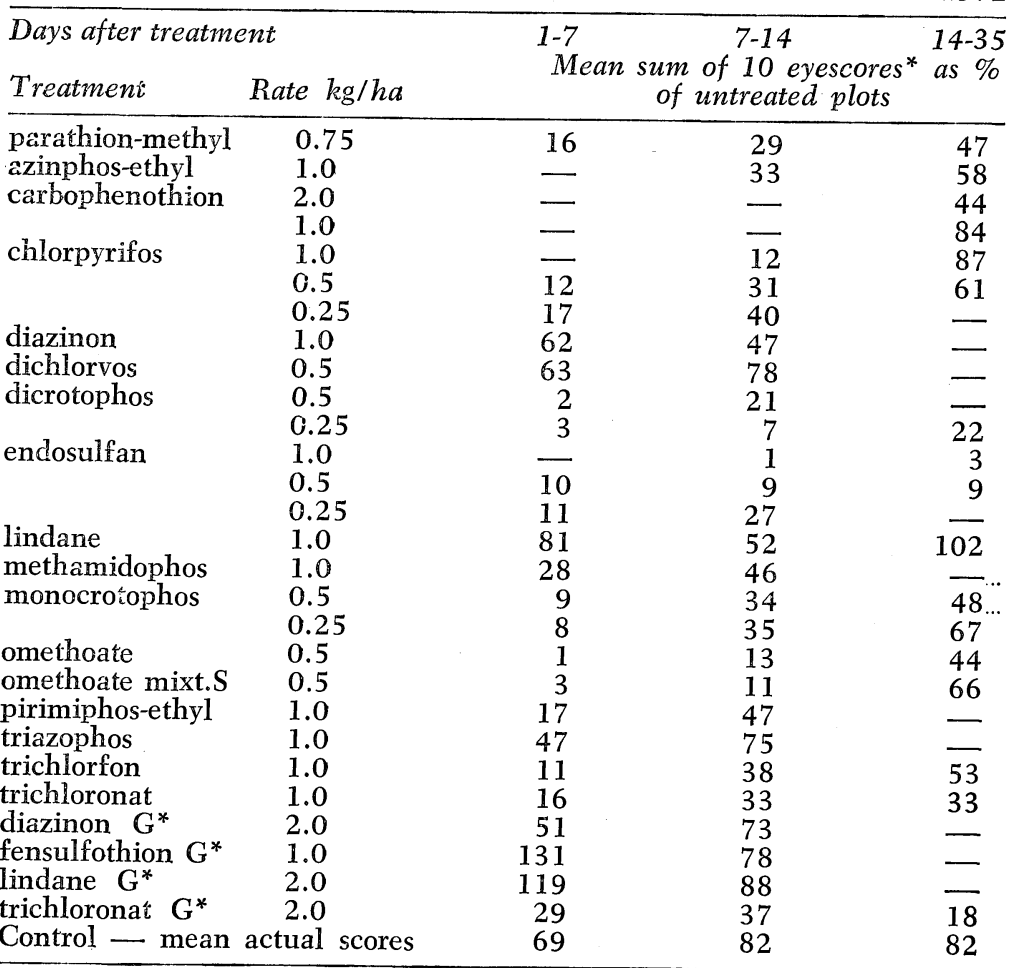
$\mathrm{G}^{*}=$ granule formulation.

* Eye score on visual basis from 0-10 where $\mathrm{O}=$ no wheat bugs visible and $10=$ very many wheat bugs visible.

$\mathrm{S}=$ Mixture of omethoate and azinphos-ethyl in equal proportions. 
Insect Pests

TABLE 2: EFFECTS OF SELECTED CHEMICALS AGAINST NYSIUS ON TWO TRIALS - 1973

\begin{tabular}{|c|c|c|c|c|c|}
\hline & $I / 4$ & $I I / 4$ & $I / 14$ & \multirow{2}{*}{$\begin{array}{c}\text { II/ } 14 \\
\text { plants }\end{array}$} \\
\hline Treatments Rat & e kg/ha & Mean & estimated $v$ & nysius per & \\
\hline parathion-methyl & 0.75 & $15.3 \mathrm{abAB}$ & $0.7 \mathrm{aA}$ & $12.9 \mathrm{abA}$ & $2.4 \mathrm{aA}$ \\
\hline dicrotophos & 0.5 & $5.0 \mathrm{aA}$ & $0.4 \mathrm{aA}$ & $12.3 \mathrm{aA}$ & $2.7 \mathrm{aA}$ \\
\hline trichloronat & 1.0 & $15.7 \mathrm{abAB}$ & $1.9 \mathrm{bA}$ & $19.3 \mathrm{bAB}$ & $4.4 \mathrm{bAB}$ \\
\hline omethoate mixture & $0.5^{*}$ & $5.7 \mathrm{aA}$ & $1.2 \mathrm{abA}$ & $16.6 \mathrm{abAB}$ & $4.0 \mathrm{abAB}$ \\
\hline chlorpyrifos & 1.0 & $16.7 \mathrm{abAB}$ & $1.3 \mathrm{abA}$ & $17.8 \mathrm{abAB}$ & $5.6 \mathrm{bB}$ \\
\hline control & & $37.5 \mathrm{bB}$ & $12.4 \mathrm{cB}$ & $28.1 \mathrm{cB}$ & $15.2 \mathrm{cC}$ \\
\hline CV \% & & 40.1 & 22.3 & 14.9 & 18.2 \\
\hline
\end{tabular}

* Mixture omethoate and azinphos-ethyl, $0.25 \mathrm{~kg} / \mathrm{ha}$ of each.

TABLE 3: COMPARISON OF TWO METHODS OF ASSESSING NYSIUS ON TURNIPS

\begin{tabular}{lccc}
\hline Treatment & Rate $\mathrm{kg} / \mathrm{ha}$ & $\begin{array}{c}\text { Visual counting } \\
\text { Mean No. for 30 plants }\end{array}$ & $\begin{array}{c}\text { No. extracted from } \\
\text { 30 plants }\end{array}$ \\
\hline parathion-methyl & 0.75 & 0 & 8 \\
methamidophos & 1.0 & 4.3 & 25 \\
methamidophos & 0.5 & 7.7 & 44 \\
fenitrothion & 1 & 8.3 & 42 \\
phorate* & 2 & 2.0 & 18 \\
trichlorfon & 1 & 7.0 & 45 \\
control & & 26.7 & 93 \\
\hline
\end{tabular}

* As $10 \%$ granules.

\section{DISCUSSION}

When these trials were started there was no information on optimum plot sizes and little information on the status, distribution, flight and migratory habits of the pest in the Canterbury area; there was also uncertainty about the period over which the pest was likely to be important for the remainder of the 1972 autumn. Thus the use of a "pepperpot" technique of distributing unreplicated plots over a wide area using as many candidate chemicals as possible was considered justified. The object was to obtain data not only on the chemicals but also on plot sizes and assessment techniques which could be used for more critical tests the following season.

The chemicals used in 1973 were selected after examination of the 1972 results (Table 1) taking into account their cost/ha compared with parathion-methyl and the fact that endosulfan may not legally be used on crops for animal consumption. From the 1973 results (a sample is given in Table 2) it can be seen that at least four insecticides used at rates which are commercially acceptable for some crops give levels of control of nysius which are comparable with parathion-methyl. These chemicals include dicrotophos at $0.5 \mathrm{~kg} / \mathrm{ha}$, trichloronat at $1 \mathrm{~kg} / \mathrm{ha}$, chlorpyrifos at $1 \mathrm{~kg} / \mathrm{ha}$ and a commercial mixture of omethoate and azinphosethyl at $0.5 \mathrm{~kg} / \mathrm{ha}$ of combined total active ingredient.

The efficiency of these chemicals, including that of parathion-methyl, as judged by the index of nysius abundance, varies from time to time. This could be due to two causes. First, nysius is most active during hot dry weather and this weather leads to a more rapid breakdown of insecticide. Thus under different climatic conditions after application the length of time for which a chemical would control nysius could vary. 
Secondly, the author has noted very considerable flight activity on warm still days. Assessment on such days could give a higher measure of nysius abundance because of the presence of newly alighted and very active insects in treated plots; insects which might, in fact, later die from the effects of the insecticides. Possibly more accurate assessments of treatment effects would be obtained if they were made only under cool cloudy conditions when bug activity is noticeably less.

The visual assessments of the numbers of nysius present are obviously well below the actual numbers present (Table 3). However if the visual assessments are only used to assess the relative merits of the chemicals being tested they are sufficiently accurate and can be made rapidly enough to carry out more widely ranging and more numerous trials.

In Table 2 the results from two sites are given. One of these sites (Site 1) was selected because of information from a spraying contractor that the farmer had asked for his services for nysius control; plants on these sites were about $8 \mathrm{~cm}$ high. The other site (Site 2) was selected by the author who determined that a nysius attack was developing, although the seedlings were barely past the cotyledon stage and there were relatively few bugs present. The site selected because of information received from the spraying contractor showed no visible advantage after control of nysius on some trial plots. The site treated much earlier in its growth showed great benefit from the chemical treatments and the remainder of the paddock in which it was situated had to be redrilled. From this and numerous other observations it is evident in many cases that, by the time the pest is abundant in a seedling brassica crop considerable loss of seedlings will have occurred. Apart from nysius a variety of pests attack seedling brassicae in Canterbury. The control of nysius is perhaps a relatively unimportant part of a total requirement to control seedling pests at an early stage of seedling growth, before insect damage causes significant loss of seedlings.

\section{ACKNOWLEDGEMENTS}

Thanks are extended to the many farmers who permitted trials to be carried out on their land, to Mr A. L. Wood who did much of the laying down and assessment of the trials and to Ms Joan Pearson who analysed the results. 